\section{Longitudinal Impacts of Home Computer Use on Primary School Children's Reading and Mathematics Achievement}

\author{
Ebrahim Talaee ${ }^{\mathrm{a},{ }^{*}}$, Kathy Sylva $^{\mathrm{b}}$, Maria Evangelouc, Omid Noroozi ${ }^{\mathrm{d}}$
}

\author{
Received: 22 September 2018 \\ Revised: $\quad 26$ September 2018 \\ Accepted: 10 October 2018 \\ ISSN: $1307-9298$ \\ Copyright (C) IEJEE \\ www.iejee.com
}

DOI: 10.26822/iejee.2018541301

\begin{abstract}
This study investigates the impact of children's Home Computer Use (HCU), both educational and recreational, on their achievement in Reading and Mathematics during primary school. The data are taken from a longitudinal study in England called Effective Provision of Preschool, Primary and Secondary Education (EPPSE). Hierarchical linear regressions were employed to investigate the main (direct) effects, and path analyses were applied to study the mediation (indirect) effects of HCU on pupils' school achievement. The main effect models indicated that HCU has very little 'extra' impact on children's school results over and beyond their prior achievement and demographic background. By contrast, results from path analyses showed a statistically significant mediation effect, through the home learning environment and self-regulation, on children's Reading and Mathematics scores. The implications of the findings for policy and practice are also discussed.
\end{abstract}

Keywords: Elementary (Primary) Education, Home Computer Use, School Achievement, Home Learning Environment

\section{Introduction}

The spread of computers and new technologies have resulted in an information technology revolution that would overturn everyone's life and work (Lean, 2016). Unlike the use of Information and Communication Technologies (ICTs) in schools, the home use of digital technologies by children and its effects have remained an under-researched area (Wang \& Minghao, 2012). This is striking since nowadays (informal) learning occurs not only at schools but also out-of-school at home (see Noroozi et al., 2012, 2016; Gu \& Xu, 2018). This gives a false picture of the extent of ownership and use of computers by children at home - which will soon reach saturation point in England, with one computer per child at home (McPake, Ploman \& Stephen, 2013) compared to a lower rate of availability of computers and their limited use in schools. This is where the ICT research community needs to think about the neglected 'secret garden' (Wellington, 2001), in other words, 'home is where the hardware is' (Facer, Furlong, Furlong \& Sutherland, 2001) by examining what children do on home computers.

Despite this research neglect, policy on the subject is quite progressive. The British government has raised its commitment to ICT deployment in education through targeting national home access to ICT and addressing ICT-based parental engagement within new parenting policies. However, studies on Home Computer Use (HCU) in the UK are mainly based on a small number of case studies and mostly focus on the anecdotal evidence of children, parents or teachers, rather than applying clinical measurements to determine their impact on children. Valentine, Marsh and Pattie (2005) noted that there has been a rapid growth in home ownership of computers and internet access, but evidence of the effect of home use of ICT on educational performance is limited. Apart from the role of computer use, ICT research is also frequently criticized on other grounds. These include small sample sizes, cross-sectional rather than longitudinal studies, use of mere- ly descriptive statistics or limited bivariate models (Gardner \& Galanouli, 2004), and focusing on technology rather than its effects on learners (Underwood, 2004). The present study aims to address some of these limitations by drawing upon data from an ongoing large scale research project in England which has collected data not only on home computing activities of children and their parents, but also on other aspects of parenting and the Home Learning Environment (HLE) which have important relationship with the home computing environment. Therefore, the main objective of this paper is to investigate the relationship between HCU and children's school achievement while monitoring inputs coming from their individual, family and HLE circumstances.

\section{Theoretical Background}

What do children do and learn on home computers?

Learning is an inseparable part of every moment of children's lives. They learn through play, talking with adults, peers and teachers, watching TV, using home computers etc. Each of these learning episodes is a function of the specific activity a child is engaged in, the social and cultural surrounding of the learning activity, and the child's personal interests, motivation and capacity to achieve a particular learning objective (Facer, Furlong, Furlong \& Sutherland, 2003). Therefore, what they learn through home PCs should be studied within an interwoven network of potential activities which children might perform on home computers, the home social and cultural resources as a context for learning, the child's personal circumstances and interests, and the availability of home computers and the Internet.

Studies show that children perform a range of activities on home computers depending on an array of social, psychological and economic factors (Livingstone \& Bober, 2004). A study on the range of activities that primary school children (focusing on Y3-Y6 pupils) engage in on home computers in

\footnotetext{
a,* Corresponding Author: Ebrahim Talaee, Tarbiat Modares University, Tehran, Iran, Email: E.talae@modares.ac.ir. bKathy Sylva, University of Oxford, UK.

Maria Evangelou, University of Oxford, UK.

¿Omid Noroozi, Tarbiat Modares University, Tehran, Iran; Wageningen University, the Netherlands. E-mail addresses: omid.noroozi@wur.nl or omid_ noruzi@yahoo.com
} 
the UK showed that children used 18 main types of the Internet applications at home (Selwyn, Potter \& Cranmer 2009). As expected, playing games came at the top (80\%) followed by making pictures (43\%), using a program on a CD (41\%), writing things (38\%), using digital cameras (28\%), while least frequent activities were computer-based applications using spreadsheets and databases (10\%).

Therefore, it is hard to cover all these different activities under an umbrella term such as ICT, and then try to link them to children's educational outcomes. Borzekowski and Robinson (2005), Wenglinsky (1998) and O'Dwyer, Russell, Bebell and Tucker-Seeley (2005) investigated the relationship between children's Reading scores and their particular computing activities, such as the frequency of computer use to send/receive emails, to edit compositions, to find information, and to create Powerpoint presentations. The drawback of this approach is the fact that these seemingly different activities are not entirely distinct from each other; indeed they might all take place simultaneously. Therefore, in order to give a bigger and more exact picture of children's home computing activities and to be able to generalise the findings across all children the present study, following other authors (e.g. O'Dwyer et al. 2005, Valentine et al. 2005, Wittwer \& Senkbeil, 2008) loosely categorised children's computing activities into two broad classes: educational and recreational use. Educational use mostly refers to school- related activities such as doing homework, searching for information for school purposes, writing essays, using presentation programs etc. Recreational use broadly covers any other activities not related to school work, such as playing games and social networking. Although there are obviously many areas of overlap between the two types of $\mathrm{HCU}$, close examination of children's activities on home computers requires some sort of arbitrary boundaries. This approach is adopted in both large-scale studies and qualitative case studies (Facer et al. 2003).

\section{$\mathrm{HCU}$ and school achievement}

Here we focus on two areas of school achievement in primary education:

HCU and literacy level. A review of literature shows that different uses of home computers have contributed to some improvement in literacy achievement, i.e. Reading, Writing and the overall English test but the results are inconsistent (see Durkin \& Conti-Ramsden, 2012; Vigdor, Ladd, \& Martinez, 2014). Valentine et al. (2005) found no significant relationship between all home ICT use measurements for educational purposes with children's achievement in Reading in $\mathrm{Y} 2$ and English in $\mathrm{Y} 6$ as measured by national assessments. However, they did find a significant relationship between the use of the Internet and educational websites with achievement for older groups in Year 11 This relationship was found after controlling for children's baseline measurements and background circumstances. By contrast, Harrison, Comber, Fisher, Haw et al. (2002) reported a significant positive relationship between ICT use and national tests for English in Y6. However, the ICT measurements in these two studies were different, so the results are not comparable. The former study used various types of activities on only home computers, while the latter used an aggregate of ICT use at home, during lessons, and at school outside lesson times. Therefore, one cannot relate such significant relationships to any of those three scenarios.

In order to overcome this problem, O'Dwyer et al (2005) investigated children's school and home use of ICT separately; and through carrying out a multi-level statistical analysis they found that 4 th graders' educational use of home computers (e.g. writing essays and searching the Internet for school-work) did not affect their performance in the English standardized test or its sub- scales in Reading and Writing. By contrast, after a 16-month trial, Jackson, Von Eye, Blocca, Barbatsis, Zhao and Fitzgerald (2006) found that children aged 10-18 who used the Internet at home obtained higher scores in standardized tests for Reading comprehension and Reading generally, after the effects of race, gender and age were partialled out. They did not control each family's socio-economic status because participant families were all from disadvantaged groups (primarily African American and single-parent households) whose annual income was $\$ 15,000$ or less. However, recreational use of home computers (e.g. playing games, searching the Internet for fun, chatting, instant messaging) was shown to be adversely and significantly related to children's achievement. O'Dwyer et al. (2005) found a negative relationship between the 4th graders' score in English Language and Arts with their HCU for recreational purposes. Similar findings were echoed by Valentine et al. (2005) for Y11's achievement in English and the levels of $\mathrm{HCU}$ for game playing.

HCU and Numeracy achievement. Similarly to literacy outcome measurements, the findings from past studies about the relationship between use of home computers and any improvement in Mathematics are sketchy. Not many studies investigated this relationship for younger learners in Key Stage 1 and those that did include this age -group did not find a significant relationship between their level of $\mathrm{HCU}$ and raised scores in Y2 national assessment of Mathematics (Valentine et al., 2005). For older children in Year 4 , still no significant relationship was found (O'Dwyer et al., 2008). But specific uses of computers in school (e.g. the use of simulation and higher order thinking software), as opposed to more general use, was shown to have a significant correlation with raised scores in Mathematics (Wenlinsky, 1998). Similar findings (i.e. non-significant relationship over and beyond other demographic circumstances) were mirrored in the longitudinal HomeNetToo project (Jackson, von Eye et al., 2006). For older children in Year6, Valentine et al. (2005) found a positive though weak significant relationship between the frequencies of $\mathrm{HCU}$ for school work and raised scores at the end of the Key Stage2 Mathematics assessment. However, in another study done by Harrison and colleagues (2002), although the above-mentioned relationship was positive, it was not statistically significant. Similar weak (Wittwer \& Senkbeil, 2008; Angrist \& Lavy, 2002) and even negative (Fuchs \& Woessmann, 2005) relationship were reported in the literature on secondary school pupils' level of HCU and their school achievement in Mathematics.

In summary, the evidence concerning the effects of $\mathrm{HCU}$ on children's school achievement is quite mixed. This can be explained by the nature of the issue under investigation and the methodological limitations of past studies. The interplay of different factors influencing children's learning outcomes - of which the use of technology is only one small element - will produce mixed results (McFarlane, Harrison, Somekh, Scrimshaw, Harrison \& Lewin, 2000; COX, Abbott, Webb, Blakeley, Beauchamp \& Rhodes, 2003; Subrahmanyam, Kraut, Greenfield \& Gross, 2000). The inextricable links between various factors related to the educational environment, pedagogy, resources, family structure, parenting etc. make it difficult to establish a direct link between the use of technology and learning outcomes. Previous studies have mostly chosen to focus on only one or other aspect. The research presented here aims to take account of as many of these aspects as possible, by drawing upon data from a large-scale study, in particular, by looking into the relationship that home computing practices might have with other parenting practices in 
home, referred to as HLE. HLE proved to be the strongest predictor of children's cognitive development in pre- and primary school education after age (Sylva et al., 2004). The literature reports a significant linear relationship between HCU and HLE (e.g. Valentine et al., 2009). Therefore, conceptually there might be an interactional relationship between HCU, HLE and children's school achievement. This relationship might confuse or mediate the impact of HCU on children's achievement, so it was necessary to design a more methodologically rigorous study that would test both direct and indirect effects.

\section{Methodology}

Proposed analytical framework for associating HCU with school achievement

A twofold analytical model is proposed. In the first layer, the direct main effects of HCU are investigated with reference to children's performance in national assessments. McFarlane et al. (2000) called this model the Direct Impact Model and this designation is retained in the present study (see Figure 1). This framework assumes that ICT learning gains are directly linked to children's scores in school assessments.

The second layer of the analytical framework, assumes that the relationship between the effects of children's $\mathrm{HCU}$ and their performance in school is affected by the influence of other factors. McFarlane et al. (2000) called this the Social -Contextual Impact Model but did not test the model in an empirical study. The present study tested both models of interaction (mediation and moderation), and the mediation effects were shown to be significant, and are reported here. The mediation framework assumes that the impact of HCU on children's attainment goes through another variable such as HLE and self-regulation. The choice of these variables was informed by the theoretical and empirical testing of all variables.

\section{Applied methods and instruments}

In order to address the topics under consideration, a quantitative, longitudinal, value-added, large scale, research strategy was adopted. Some of the methodological limitations of ICT research (as discussed by Gardner \& Galanouli, 2004) have been addressed in this study by using a large sample longitudinal study which includes a range of covariates. It draws upon the data from the study called Effective
Provision of Preschool, Primary and Secondary Education (EPPSE), the aim of which was to investigate the effects of pre-school education and care on children's development for children aged 3-7 years old. However, it was extended to study the same cohort to the end of compulsory education at age 16 (1997-2013). The research team collected a wide range of data on the developmental profiles of nearly 3,000 children, background circumstances related to the children themselves, their parents and their HLE, and the pre-schools, primary and secondary schools they attended. Various methods of data collection were used including one-to-one parental interviews, postal questionnaires for parents, questionnaires for pupils on their attitudes to school, teachers' assessment of pupils' social and behavioural development, one-to-one standardized assessments of children on their cognitive development and national assessment scores for the end of each Key Stage. The sample was nationally representative, from Six Local Authorities in England (see Sylva et al., 2004).

Data on the use of home computers by children on their own and with their parents were obtained through a questionnaire posted to families. The data were collected at two points of time: first when children were in KS1 ( $Y 1$ and $\mathrm{Y} 2$ ) and then when they were coming to the end of KS2 (Y5 and Y6). For the rest of data we used the national assessment tests as research instruments. Frequency questions were answered on a 5-point Likert scale: 'never', 'hardly ever', 'occasionally', '1 or 2 times a week', 'everyday'.

\section{Findings}

\section{HCU and children's school achievement in Year2}

Analyses showed a quadratic trend in the scores where the highest mean score belong to moderate users of home computers, decreasing on both sides (Figure 2). This indicates an optimal level of $\mathrm{HCU}$ for both educational (HCUfE) and recreational (HCUfR) purposes. It is interesting to see that non-users of home computers scored lowest (below the sample mean) for both Mathematics and Reading. Non-users of home computers might in fact be those who do not own a home computer and therefore, it reflects a proxy for the children's socio-economic status, although the dataset provides a thorough measure of SES based on their parental occupation and annual income. Further analyses confirmed the match between these two measurements. Also post-hoc tests of Analysis of Variance (ANOVA) showed that there was a significant difference be-

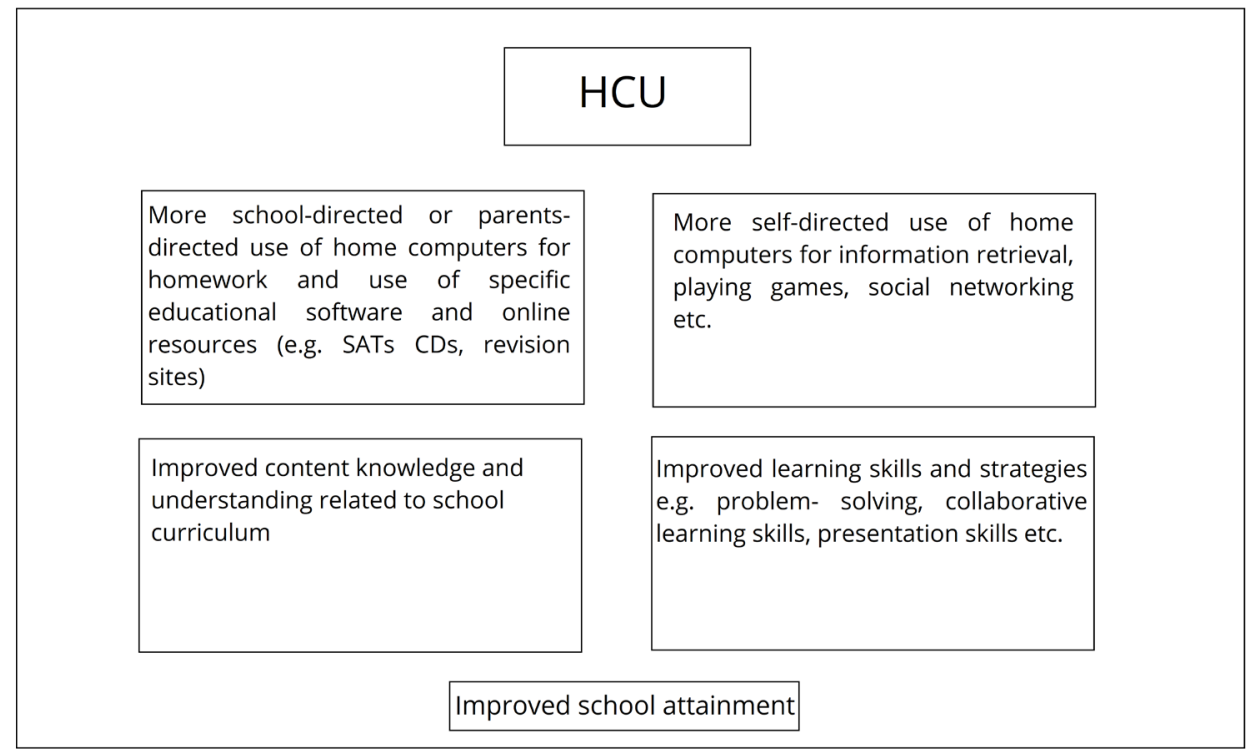

Figure 1. Driect Impact Model 
tween the mean scores of non-users and all other groups except everyday users, $F(4)=14.36, p<.01$ (for HCUfE and Reading) and $F(8)=4.30, p<.01$ (for HCUfR and Reading). Similar patterns were repeated for Mathematics.

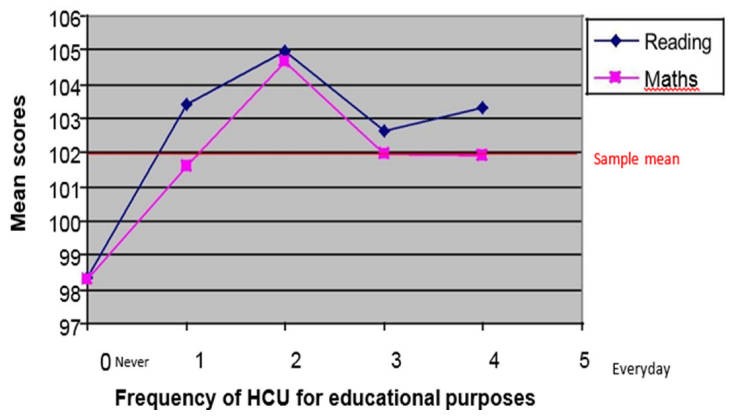

Figure 2. HCU for educational purposes and Y2 national assessments

Recreational use of home computers also showed a similar quadratic relationship with Reading and Mathematics scores. Both non-users and everyday users of home computers for recreational purposes scored lower than moderate users (Figure 3). In contrast to educational use, high users of home computers for recreational use scored much lower than their counterparts in the educational use group. This might reinforce the findings of past studies that suggested that extensive game playing on computers is associated with weaker performance in school (e.g. Valentine et. al., 2005).

The next step of the analyses was to include covariates that were theoretically and empirically shown to confound effects on children's school achievement. Therefore, hierarchical linear regressions were applied. Five stepwise incremental models are produced and reported here to demonstrate the stage at which the effects of HCU fade away. Model 1 has only one explanatory variable (i.e. HCU) and model 5 has the most. Each model includes the explanatory variables of the previous model plus its own ones. The results show that children's HCU for education was positively associated with their reading scores in Y2 after taking into account their prior attainment; but after inputting family circumstances, HCU for education was no longer a significant predictor for their reading scores. Recreational use of home computers showed a negative but not significant relationship with children's reading scores after the baseline measurement was taken into account (Table 1).

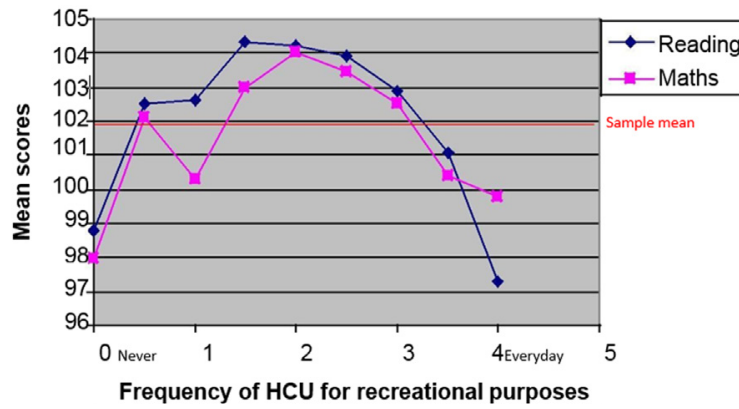

Figure 3. HCU for recreational purposes and $\mathrm{Y} 2$ national assessments

For Mathematics, the data showed that levels of educational use of home computers in KS1 was a weak but significant predictor of children's Mathematics scores in Y2 after controlling for their prior performance, and individual circumstances like gender and early-years developmental problems. However, as with Reading, after taking into account the effects of family and HLE circumstances, this weak relationship faded away (Table 2 ).

\section{HCU and children's school achievement in Year6}

The scatter plots show an inverted U-shape relationship similar to that reported for KS1. The weakest performance in all three subjects belongs to non- and low users of home computers (Figure 4). Post-hoc tests of ANOVA also confirmed that there was a significant difference between the mean score of the non/low users (0-3 on 12 point HCUfE scale) and that of moderate users (4-10) for Mathematics and Reading but not for Writing: $F(12)=4.01$, $p<.01$ for Mathematics and $F(12)=2.42, p<.01$ for Reading.

Table 1. Hierarchical linear regression results for Reading Y2

\begin{tabular}{|c|c|c|c|c|c|}
\hline Models/ variables & $\begin{array}{l}\text { Model } 1 \\
\text { (HCU only) }\end{array}$ & $\begin{array}{l}\text { Model } 2 \\
\text { (Baseline } \\
\text { Mesaure) }\end{array}$ & $\begin{array}{c}\text { Model } 3 \\
\text { (Individual block) }\end{array}$ & Model 4 & $\begin{array}{l}\text { Model } 5 \\
\text { (HLE block) }\end{array}$ \\
\hline HLE & & & & & $.06^{* *}$ \\
\hline Mother's education & & & & $.07^{* *}$ & $.06^{*}$ \\
\hline SES & & & & $-.11^{* \star}$ & $-.11^{\text {* }}$ \\
\hline FSM & & & & ns & ns \\
\hline No. of siblings & & & & ns & ns \\
\hline Gender & & & $.06^{* *}$ & $.08^{* *}$ & $.06^{* *}$ \\
\hline $\begin{array}{l}\text { Ethnicity (Compared to White } \\
\text { UK heritage) }\end{array}$ & & & $\begin{array}{r}-.05^{\star} \text { (Black Afri- } \\
\text { can; other ethnic } \\
\text { groups ) }\end{array}$ & ns & ns \\
\hline EAL & & & $.06^{* *}$ & $.06^{\star \star}$ & $.06^{* *}$ \\
\hline Developmental problems & & & $.05^{*}$ & $.05^{*}$ & $.05^{*}$ \\
\hline Pre-reading at entry to school & & $.59^{* *}$ & $.57^{* *}$ & $.50^{* *}$ & $.49^{* \star}$ \\
\hline HCU for Education & $.17^{* *}$ & $.05^{* *}$ & $.04^{* *}$ & ns & ns \\
\hline $\begin{array}{l}\text { HCU for } \\
\text { Recreation }\end{array}$ & $-.11^{* *}$ & ns & ns & ns & ns \\
\hline Variance explained & .020 & .357 & .370 & .395 & .398 \\
\hline Constant & .05 & .04 & .04 & .03 & .03 \\
\hline
\end{tabular}


Table 2. Hierarchical linear regression results for Reading Y2

\begin{tabular}{|c|c|c|c|c|c|}
\hline Models/ variables & $\begin{array}{l}\text { Model } 1 \\
\text { (HCU only) }\end{array}$ & $\begin{array}{l}\text { Model } 2 \\
\text { (Baseline } \\
\text { Mesaure) }\end{array}$ & $\begin{array}{c}\text { Model } 3 \\
\text { (Individual block) }\end{array}$ & Model 4 & $\begin{array}{l}\text { Model } 5 \\
\text { (HLE block) }\end{array}$ \\
\hline HLE & & & & & $.07^{* *}$ \\
\hline Mother's education & & & & $.08^{\star *}$ & $.08^{*}$ \\
\hline SES & & & & $-.09^{\star \star}$ & $-.11^{\star *}$ \\
\hline FSM & & & & ns & ns \\
\hline No. of siblings & & & & ns & ns \\
\hline Gender & & & $-.11^{\star *}$ & $-.10^{* *}$ & $-.11^{\star *}$ \\
\hline $\begin{array}{l}\text { Ethnicity (Compared to White } \\
\text { UK heritage) }\end{array}$ & & & ns & ns & ns \\
\hline EAL & & & ns & ns & ns \\
\hline Developmental problems & & & $.05^{*}$ & $.05^{*}$ & $.05^{*}$ \\
\hline Pre-reading at entry to school & & $.50^{\star *}$ & $.51^{\star *}$ & $.45^{\star \star}$ & $.44^{* \star}$ \\
\hline HCU for Education & $.13^{* *}$ & $.06^{* *}$ & $.07^{* *}$ & ns & ns \\
\hline $\begin{array}{l}\text { HCU for } \\
\text { Recreation }\end{array}$ & $-.05^{\star *}$ & ns & ns & ns & ns \\
\hline Variance explained & .011 & .262 & .279 & .301 & .304 \\
\hline Constant & .04 & .04 & .04 & .03 & .03 \\
\hline
\end{tabular}

*Significant at $p=$ or $<.05 ;$ **Significant at $p=$ or $<.01$; \# just failed to reach significance level at $p=.05 ;$ ns: non-significant

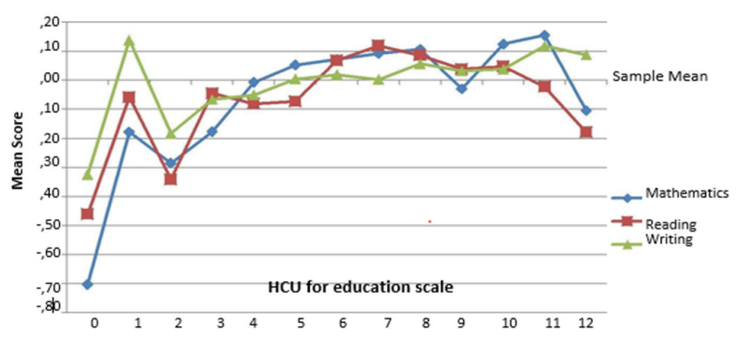

Figure 4. HCU for education and $\mathrm{Y} 6$ school attainment (bivariate analysis)
The scatter plots also confirm the linear positive relationship between recreational use of home computers and children's Mathematics scores, and a negative (though not statistically significant) relationship with Reading and Writing. The analyses from the hierarchical linear regression models show that after controlling for children's prior achievement and their demographic background (Model 5), the relationship became non-significant for both educational and recreational use of home computers, as well as for children's reading and writing scores in Year6 (Table $3)$.

Analyses of the effects of using home computers in KS2 on children's Mathematics scores in Year6 showed that af-

Table 3. Significant predictors of Reading Y6

\begin{tabular}{|c|c|c|c|c|c|}
\hline Models/ variables & $\begin{array}{l}\text { Model } 1 \\
\text { (HCU only) }\end{array}$ & $\begin{array}{l}\text { Model } 2 \\
\text { (Baseline } \\
\text { Mesaure) }\end{array}$ & $\begin{array}{c}\text { Model } 3 \\
\text { (Individual block) }\end{array}$ & Model 4 & $\begin{array}{c}\text { Model } 5 \\
\text { (HLE block) }\end{array}$ \\
\hline \multicolumn{6}{|l|}{ K2 HLE } \\
\hline $\begin{array}{l}\text { Child's independent learning } \\
\text { activities }\end{array}$ & & & & & $.08^{* *}$ \\
\hline $\begin{array}{l}\text { Parents' informal learning } \\
\text { activities }\end{array}$ & & & & & $.05^{\star \star}$ \\
\hline Mother's education & & & & $.07^{* *}$ & $.06^{* *}$ \\
\hline SES & & & & $-.09^{* \star}$ & $-.09^{* *}$ \\
\hline FSM & & & & $-.06^{\star *}$ & $-.06^{\star \star}$ \\
\hline Gender & & & $.05^{*}$ & $.06^{* *}$ & $.04^{*}$ \\
\hline $\begin{array}{l}\text { Ethnicity (Compared to White } \\
\text { UK heritage) }\end{array}$ & & & $-.05^{\#}$ (Pakistani) & ns & ns \\
\hline Reading Year 2 & & $.70^{\star *}$ & $.69^{* *}$ & $.63^{* *}$ & $.60^{* \star}$ \\
\hline HCU for Education & $.06^{\#}$ & $.06^{* *}$ & $.07^{* *}$ & ns & ns \\
\hline $\begin{array}{l}\text { HCU for } \\
\text { Recreation }\end{array}$ & $-.04 n s$ & $.02 \mathrm{~ns}$ & ns & ns & ns \\
\hline Variance explained & .002 & .49 & .495 & .51 & .53 \\
\hline Constant & .05 & .03 & .03 & .03 & .03 \\
\hline
\end{tabular}


ter children's prior achievements were taken into account, primary significant effects faded away.

\section{Interaction models}

To deal with possible moderating or mediating effects of HLE and self- regulation on the relationship between children's HCU and school performance, the interaction product term was first applied to test the moderating effects, but the regression coefficients failed to reach a significance level. Therefore, it was decided not to go further along this line, but to investigate the mediating effects of HLE and self - regulation. Using path analysis, models were made for all three school achievement measurements, but only Mathematics and Reading showed a significant mediating effect of HLE/self-regulation.

Mediating effects of HLE. Figure 5 shows the path model for the mediating effect of one aspect of HLE in Key Stage2, which relates a child's independent learning activities (reading on their own, doing homework, painting, drawing and making models on their own) to the relationship between HCU for educational purposes and a child's performance in Y6 Reading. The path model reports the theoretical relationships between components of the model, and it is based mainly on past studies and theoretical frameworks. The presented model tests the hypothesis that educational use of home computers might have some positive effects on children's non-computer learning activities at home (e.g. reading) which in turn might positively influence children's performance in Reading assessment. This model, as stated in section 3.1, is referred to as the Social-Contextual Impact Model (McFarlane et.al, 2000) and is tested in the present study. The model shows that the indirect (or mediating) effect is statistically significant (path coefficient $=.08, p<.05$ ). The direct effect, however, was shown to be statistically non-significant. The path coefficients are reported while the influences of other variables are partialled out.

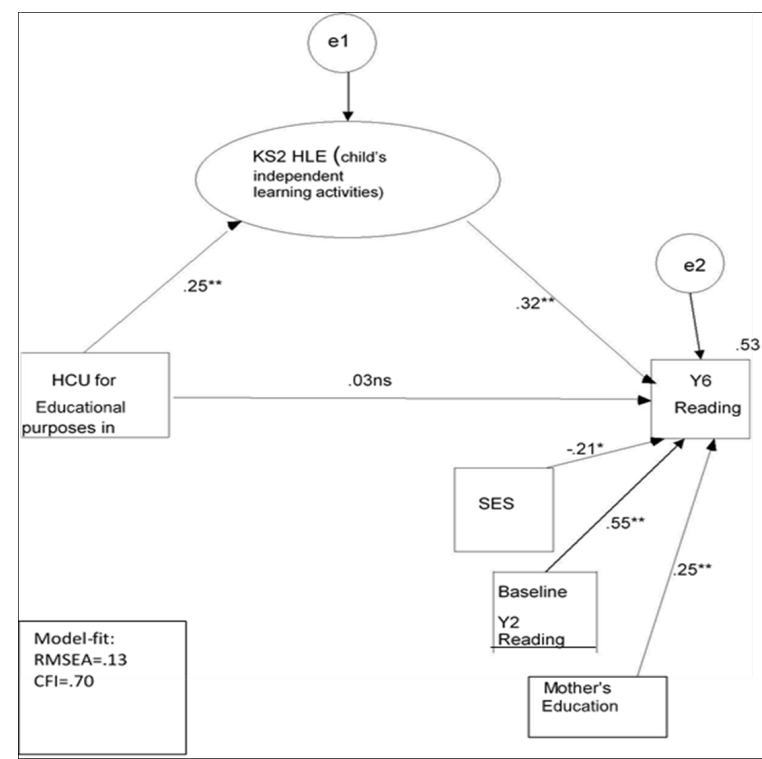

Figure 5. Path model for mediating effect of HLE on the relationship between HCUfE and Mathematics Y6 (* significant at $p<.05 * *$ significant at $p<.01$ )

Mediating effects of self-regulation. The hypothesis here is that educational use of home computers has some positive effects on children's self-regulated learning strategies which in turn positively affect children's performance in Mathematics. Children's self-regulation was assessed from entry to the study at age 3 up to age 12 through a questionnaire filled out by pupils' teachers who had been with them for at least one school term. For the primary school period, a Strength and Difficulties Questionnaire was applied (Goodman, 1997). A principal component analysis and Confirmatory Factor Analysis (CFA) were carried out to identify the underlying dimensions of social behaviour. Four factors, including self-regulation, were identified. This included items such as pupils liking to work things out for themselves; pupils rarely seeking help, choosing activities on their own, and being able to move on to a new activity after finishing a task. Figure 6 shows that the direct effect of HCU for educational purposes on children's mathematics in $\mathrm{Y} 6$ was not significant (path coefficient $=.04$ ) after controlling for their prior attainment level in Y2 and the effects of their demographic circumstances. However, the indirect effect through improving a child's self-regulation is shown to be statistically significant (path coefficient $=.11, p<.01$ ). This effect is the value- added net effect because it is over and beyond the effects of background circumstances and takes account of children's baseline measurements (i.e. Mathematics Y2).

\section{Discussion}

Table 4 summarizes and compares the main effects of the two types of HCU (i.e. educational and recreational) and other demographic background circumstances on children's school achievement measurements at two points in Year2 and Year6. It reports the extent of the effect from the final model (i.e. Model 5) of the hierarchical linear regression data analysis in which baseline measurements and a child's individual, family and HLE circumstances are included in the equation. Therefore, Figure 6 shows the net value-added effects. For $\mathrm{HCU}$, the table shows that the amount and type of HCU do not have an extra 'impact' on children's school achievement for Reading and Mathematics in primary school. However, a child's individual, family and HLE circumstances continue to predict academic outcomes (both attainment and progress) in Year6. The extent of the effect in Table 4 reports the magnitude of effects for each predictor on the progress a child has made from a baseline measurement. For Year2, the progress is also measured from the time children entered primary school and for Year6; the baseline is Year 2. For Reading and Mathematics, gender, ethnicity and pre-school developmental problems, family socio-economic status (SES), the mother's educational level, eligibility for Free School Meals (FSM) and HLE showed significant effects that are distinct from the effects of all other circumstances considered.

A comparison of the extent of the effect from various background circumstances across the two key stages shows that a child's individual, family and HLE circumstances remain significant predictors of attainment/progress in Year6, although their influence is weaker than when children were in Year2. Taken together, one can conclude that children who belong to the highest SES category (i.e. professional non-manual group) have significantly higher attainment and progress in school, net of the influence of family income and educational level, although there is a positive correlation between family SES, income level and educational level. HLE also showed a consistent significant effect on both Reading and Mathematics in primary school after the effects of a child's individual and family circumstances are partialled out. Early years HLE significantly predicted Y2 Reading and Mathematics, and KS2 HLE significantly predicted Year6 Reading and Mathematics. The effect sizes of early years HLE and KS2 HLE are not comparable because different measurements were applied. However, they both include parenting and child practices in the home. One big difference between early years HLE and KS2 HLE is that as children are 11/12 in KS2, they do more independent activities at home than those involv- 
ing their parents. Moreover, the nature of their activities becomes more diverse. Therefore, instead of having one measurement for HLE in KS2, the statistical analyses revealed three underlying aspects of HLE. The strongest aspect of HLE for predicting Reading and Mathematics was 'children's independent learning activities' such as reading on their own. In addition, 'parents' informal learning activities' such as taking the child to libraries and museums in KS2 showed a significant relationship with raised scores in Reading at age 11.

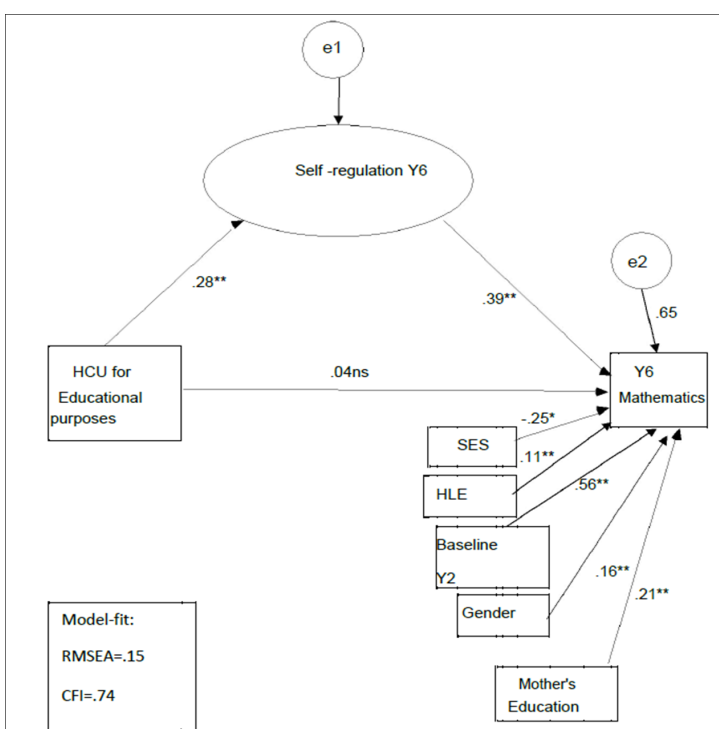

Figure 6. Path model for mediating effect of self-regulation on the relationship between HCUfE and Reading Y6 (* significant at $p<.05 * *$ significant at $p<.01$ )
To sum up, the overarching aim of this study was to investigate whether learning gains through $\mathrm{HCU}$ are associated with children's performance in schools. The current study showed that using home computers for both educational and recreational purposes does not have an 'extra' direct impact on children's performance and progress in Reading, Mathematics and Writing in primary school over and beyond what could be expected based on their prior achievement, and individual, family and HLE circumstances. However, it was children's family circumstances, particularly socio-economic status and the mother's educational level and HLE, which "overcame" the initial positive influence of HCU for education on children's school outcomes. This finding is compatible with the results from most other studies on primary pupils such as Valentine et al. (2005), O'Dwyer et al. (2005 \& 2008), and Jackson et al. (2006). This can be partially explained by referring to Nechyba, McEwan and Older-Aguilar's (1999) argument about the inextricable link between various factors that influence a child's school achievement. One can argue that children's HCU is a small factor within an array of more important ones.

One further explanation for this could be related to the 'time-on-task' factor. The relatively low level of daily HCU for both educational and recreational purposes by primary pupils in the present study might create a 'floor effect'. This might have reduced the explanatory power of the models. The current study reported that in KS1 fewer than $3 \%$ were daily users of home computers for educational purposes and a further $20 \%$ reported weekly use. Similarly, in KS2 only 14\% of pupils were reported to be daily users. Although, as pupils grew up to age 10/11, their frequency of HCU for educational purposes increased, it was still infrequent compared to the reported proportions of daily users among KS3 and KS4 pupils from other studies

Table 4. Summary of significant HCU and background characteristics main effects on Year2 and Yea 6 outcomes

\begin{tabular}{|c|c|c|c|c|c|}
\hline Variables & Labels & $\begin{array}{l}\text { Reading } \\
\text { Year } 2\end{array}$ & $\begin{array}{l}\text { Reading } \\
\text { Year } 6\end{array}$ & $\begin{array}{l}\text { Mathematics } \\
\text { Year } 2\end{array}$ & $\begin{array}{l}\text { Mathematics } \\
\text { Year } 6\end{array}$ \\
\hline HCU for education & & ns & ns & ns & $\mathrm{ns}$ \\
\hline HCU for recreation & & ns & ns & ns & ns \\
\hline Baseline & & .49 & .60 & .44 & .60 \\
\hline \multicolumn{6}{|l|}{ Measure } \\
\hline Child factors & Compared to & & & & \\
\hline Gender (Girls) & boys & .06 & .04 & -.11 & -.09 \\
\hline Ethnicity (Pakistani) & White UK & & & & -.04 \\
\hline $\begin{array}{l}\text { Early years developmental } \\
\text { problems (none) }\end{array}$ & $\begin{array}{l}\text { Having } 1^{+} \text {developmental } \\
\text { problem }\end{array}$ & .06 & & .05 & \\
\hline $\begin{array}{l}\text { Early years behavioural prob- } \\
\text { lems (none) }\end{array}$ & $\begin{array}{l}\text { Having } 1^{+} \text {behavioural } \\
\text { problem }\end{array}$ & & & & \\
\hline Family factors & & -.11 & -.09 & -.08 & -.08 \\
\hline SES (high to low) & & .06 & .06 & .07 & .13 \\
\hline $\begin{array}{l}\text { Mother's education (low to } \\
\text { high) }\end{array}$ & & -.04 & -.06 & & \\
\hline $\begin{array}{l}\text { Eligibility for Free School Meal } \\
\text { (proxy for economic status) }\end{array}$ & Non-FSM & & & & \\
\hline HLE & & .06 & & .07 & \\
\hline Early years HLE & & & .08 & & .07 \\
\hline $\begin{array}{l}\text { KS2 HLE (child independent } \\
\text { learning activities) }\end{array}$ & & & .05 & & \\
\hline $\begin{array}{l}\text { KS2 HLE (parents' informal } \\
\text { learning activities) }\end{array}$ & & & & & \\
\hline
\end{tabular}


(e.g. $34 \%$ of KS4 pupils were reported as daily users in Valentine et al., 2005). Most investigations on the effects of computer use have found more consistent and extensive effects among older pupils in KS3 and KS4 (e.g. Harrison et al., 2005). Furthermore, even studies on computer use in the classroom show that spending a small amount of time on a computer-based task was not significantly associated with children's performance in the related assessments (e.g. O'Dwyer et al., 2005).

Moreover, studies have shown that during primary school, the part that family and parenting practices play in children's school success is much stronger than that for secondary school pupils and it is even more influential than any in-school initiative. For instance Mann, Shakeshaft, Becker, and Kottkamp (1999) found that almost $70 \%$ of the variation in pupils' scores was associated with factors related to family SES, parenting, and home life and only 30\% was associated with school-based educational initiatives. Despite the statistically non-significant results of the main effect models, the mediating effect models revealed an interesting relationship between educational use of home computers, HLE, self-regulation and two of the outcome measurements. In the first model, educational use of home computers in KS2 was significantly associated with one aspect of KS2 HLE (e.g. child's independent learning activities at home) which itself was significantly associated with Y6 Reading scores. Considering the relatively large sample used in the present study, the mediating effects of HCU on Reading scores through HLE is a significant finding. However, the available data in the EPPSE dataset do not allow pressing this relationship further, and there will be a need for additional investigation as to why and how HCU further stimulates children's independent academic activities at home (e.g. reading and drawing) which in turn positively influence their Reading scores. There are no data available on specific educational activities of children on home computers, but one might speculate that some computer-based educational activities (such as preparing a school newsletter) require and stimulate children to read, understand and summarise both paper and electronic resources. These reading and beyond-reading activities which are often carried out cooperatively might then positively influence children's performance in Reading assessment.

Similarly, the second mediating model showed a significant indirect relationship between HCU for educational purposes and Year6 Mathematics scores through children's self-regulation scores. Again, the data cannot be used to claim a causal relationship, but one might explain this mediating relationship through self-regulation theories (e.g. Zimmerman, 2002) and the empirical evidence for a significant relationship between children's self-regulation and their school achievement (e.g. Sylva et al., 2008). One might speculate that the capabilities of new technologies might afford self-regulated learning opportunities for users, which in turn might positively influence their performance in mathematics assessment. Some of these opportunities are: the provision of an exploratory environment for children's development of experiential discovery learning; the creation of a learning environment in which help-seeking is an attractive option when problems are encountered; and learning to collaborate with other players in group game playing. Furthermore, the original EPPSE study (Sylva et al., 2008) and other similar investigations have shown that children's self-regulation is a strong predictor of their performance in school achievement assessments. This chain of relationships is shown to be statistically significant in the present study, but why and how this might occur in practice requires further investigation.

\section{Conclusion}

The findings of the present study maintain that through the use of home computers, children gain some learning skills and strategies such as self-regulated Learning, problem-solving abilities, independent and autonomous learning activities, and collaborative learning skills. This theoretical understanding of the benefits of ICT for learning is based on the views of constructivists (e.g. Pappert, 1980) and socio- constructivists (e.g. Säljö, 1998) concerning learning with computers (see Noroozi et al., 2016, 2017, 2018). This indirect relationship through self- regulation was not significant for Reading and Writing in neither Year 6 nor any of the Y2 school achievement outcomes. Therefore, it seems that subject area and age are two important factors in the indirect impact-model.

One contribution of the present research is that it expanded the indirect-impact model, originally proposed by McFarlane et al. (2000). This is because the model was primarily presented for school-based ICT use. Use of the model for HCU and applying it within an array of a child's individual, family and HLE circumstances showed that HCU might not only influence the enhancement of meta-cognitive skills such as self-regulation, but it might also stimulate some aspects of the HLE for Y6 children. The HLE then influences children's performance in schools. The current study provides empirical evidence for only some aspects of HLE and Reading scores in Year6. Further studies are required to confirm the findings and test other aspects of HLE and other subject areas.

A policy implication of this study is relevant to the government's 'Home Access' program (BECTA, 2008). The study showed that nearly all (90\%) children use computers at home and that frequency of use increased with age. Therefore, a main part of children's home time is filled with $\mathrm{HCU}$. However, the magnitude of the direct effects of HCU for educational purposes on children's school performance is low and non-significant after controlling for other factors. This might be a warning for the government against huge investment on ICT for education. Children instead spend most of their HCU time playing games. However, certain uses of HCU have positive impacts on children's school performance, which come through enhancing and stimulating other capabilities (e.g. self-regulation) and educational activities (e.g. HLE). Therefore, ICT policies should aim at strategies and programs that make this indirect link stronger. For instance, a stronger home-school link is required in which teachers lead children and families to use particular software and online resources which are in line with those capabilities and educational activities. A final implication of this study for practice is that parental programs need to seriously address HLE and children's activities if they want to take advantage of the benefits of home computers. There can be initiatives in which familial and individual activities are planned around home computers.

\section{References}

Angrist, J., \& Lavy, V. (2002). New evidence on classroom computers and pupil learning. The Economic Journal, 112, 735-765.

BECTA (2008). Extending Opportunity: Final Report of the Minister's Taskforce on Home Access to Technology. Coventry, British Educational Communications and Technology Agency.

Borzekowski, D. L. G. \& Robinson, T. N. (2005). The remote, the mouse, and the no. 2 pencil: The household media environment and academic achievement among third grade students. Archives of Pediatrics and Adolescent Medicine, 159, 607-613. 
Cox, M. J., Abbott, C., Webb, M., Blakeley, B., Beuchamp T. \& Rhodes, V. (2003). ICT and attainment: $A$ review of the Research Literature. a report to the DfES, London, DfES.

Durkin, K., \& Conti-Ramsden, G. (2012) Frequency of educational computer use as a longitudinal predictor of educational outcome in young people with specific language impairment. PLOS ONE, 7, e52194.

Facer, K., Furlong, J., Furlong, R. \& Sutherland, R. (2001). Home is where the hardware is: Young people, the domestic environment and 'access' to new technologies. In Moran-Ellis, I. H. A. J. (Ed.) Children, Technology and Culture. London, RoutledgeFalmer.

Facer, K., Furlong, J., Furlong, R. \& Sutherland, R. (2003). Screenplay, London, Routledge.

Fuchs, T. \& Wößmann, L. (2005). Computers and student learning: Bivariate and multivariate evidence on the availability and use of computers at home and at school. CESIfo Institute for Economic Research at the University of Munich.

Gardner, J. \& Galanouli, D. (2004). Research into Information and Communications Technology in Education: disciplined inquiries for telling stories better. Technology, Pedagogy and Education, 13, 147-161.

Goodman, R. (1997). The strengths and difficulties questionnaire: A research note. Journal of Child Psychology and Psychiatry, 38, 581-586.

Gu., X., \& Xu, H. (2018). Missing piece in understanding student learning: out-of-school computer use. Journal of Educational Computing Research. https:// doi.org/10.1177/0735633118755494

Harrison, C., Conber, C., Fisher, T., Haw, K. (2002). Imapct 2: The impact of Information and Communication Technologies on Pupil Learning and Attainment. ICT in Schools Research and Evaluation. Coventry, BECTA.

Jackson, L. C., Von Eye, A., Biocca, F. A., Barbatsis, G., Zhao, Y. \& Fitzgerald, H. E. (2006). Does Home Internet Use Influence the Academic Performance of LowIncome Children? Developmental Psychology, 42, 429-435.

Lean, T. (2016). Electronic Dreams: How 1980s Britain learned to love the computer. Bloomsbury Sigma.

Livingstine, S. \& Bober, M. (2004). Taking up Online Opportunities? Children's Uses of the Internet for Education, Communication and Participation. E-Learning, 1, 395-419.

Mann, D., Shakeshaft, C., Becker, J., \& Kottkamp, R. (1999). West Virginia story: Achievement gains from a statewide comprehensive instructional technology program. Available: http://www.mf.org/pubs/ ME155.pd.

Statewide comprehensive instructional technology program. Available: http://www.mf.org/pubs/ ME155.pd. McFarlane, A., Harrison, C., Somekh, B., Scrimshaw, P., Harrison, A. \& Lewin, C. (2000). Impact Preliminary Study1. Coventry, Becta.

McPake, J., Plowman, L. \& Stephen, C. (2013). Pre-school children creating and communicating with digital technologies in the home. British Journal of
Educational Technology, 44, 421-443.

Nechyba, T., Mcewan, P. \& Older-Aguilar, D. (1999). The impact of Family and Community Resources on Student Outcomes: An Assessment of the International Literature with implications for New Zealand. Wellington: New Zealand Ministry of Education.

Noroozi, O. (2017). Considering students' epistemic beliefs to facilitate their argumentative discourse and attitudinal change with a digital dialogue game. Innovations in Education and Teaching International. http://dx.doi.org/10.1080/14703297.2016.120811 2.

Noroozi, O., Biemans, H.J.A., \& Mulder, M. (2016). Relations between scripted online peer feedback processes and quality of written argumentative essay. Internet and Higher Education, 31, 20-31.

Noroozi, O., Kirschner, P., Biemans, H.J.A., \& Mulder, M. (2018). Promoting argumentation competence: Extending from first- to second-order scaffolding through adaptive fading. Educational Psychology Review, 30, 153-176.

Noroozi, O., Weinberger, A., Biemans, H.J.A., Mulder, M., \& Chizari, M. (2012). Argumentation-based computer supported collaborative learning (ABCSCL). A systematic review and synthesis of fifteen years of research. Educational Research Review, 7, 79-106.

O'Dwyer, L. M., Russell, M., Bebell, D. \& Tucker-Seeley, K. R. (2005). Examining the relationship between home and school computer use and students' English/ Language arts test scores. Journal of Technology, Learning and Assessment, 3, 1-45.

O'Dwyer, L. M., Russell, M., Bebell, D. \& Tucker -Seeley, K. R. (2008). Examining the Relationship between Students' Mathematics Test Scores and Computer Use at Home and at School. Journal of Technology, Learning and Assessment, 6, 1-45.

Papert, S. (1980). Mindstorms: Children, Computers and Powerful Ideas, New York, Basic Books.

Säljö, R. (1998) . Thinking with and through artefacts: the role of psychological tools and physical artefacts in human learning and cognition. In Faulkner, D., Littleton, K. \& Woodhead, M. (Eds.) Learning Relationships in the Classroom. London, Routledge/ Open University.

Selwyn, N., Potter, J. \& Cranmer, S. (2009). Primary pupils' use of information and communication technology at school and home. British Journal of Educational Technology, 40, 919-932.

Subrahmanyam, K., Kraut, R. E., Greenfield, P. M. \& Gross, E. F. (2000). The impact of Home Computer Use on Children's Activities and Development. The Future of Children, 10, 123-144.

Sylva, K., Melhuish, E., Sammons, P., Siraj-Blatchford, I., \& Taggart, B. (2004). Effective provision of pre-school education project (EPPE): Technical Paper 12. The final report. London: Institute of Education, University of London.

Sylva, K., Melhuish, E., Sammons, P., Siraj-Blatchford, I., \& Taggart, B. (2008). Final Report from the Primary Phase: Pre-school, School and Family influences on Children's Development During Key Stage 2 (Age 7-11). London, DCSF. 
Underwood, J. (2004). Research into information and communication technologies: where now? Technology, Pedagogy and Education, 13, 135-145.

Valentine, G., Marsh, J. \& Pattie, C. (2005). Children and Young People's Home Use of ICT for Educational Purposes: The Impact on Attainment at Key Stages 1-4. London, DfES.

Vigdor, J. L., Ladd, H. F., Martinez, E. (2014). Scaling the digital divide: Home computer technology and student achievement. Economic Inquiry, 52, 11031119.

Wang, Q., \& Minghao, L. (2012). Home computer ownership and Internet use in China: Trends, disparities, socioeconomic impacts, and policy implications. Journal of the Internet, 17. University of Illinois at Chicago University Library.

Wellington, J. (2001). Exploring the secret garden: the growing importance of ICT in the home. British Journal of Educational Technology, 32, 233-144.

Wenglinsky, H. (1998). Does it compute? The Relationship between Educational Technology and Student Achievement in Mathematics. Princeton, NJ, Educational Testing Service Policy Information Centre.

Wittwer, J. \& Senkbell, M. (2008). Is students' computer use at home related to their mathematical performance at school. Computers and Education, $50,1558-1571$

Zimmerman, B. J. (2002). Becoming a self-regulated learner. Theory Into Practice, 41, 65-70. 